\title{
Information Society Perspective in Turkey: Literature Study
}

DOI: $10.26466 /$ opus. 937283

\author{
Tuğba Tunacan * - Cemalettin Hatipoğlu ** \\ * Asst.Prof.Dr., Bolu Abant İzzet Baysal University, Bolu / Turkey \\ E-Mail: tugbatunacan@ibu.edu.tr \\ ORCID: $\underline{0000-0002-3207-8932}$ \\ ** Asst.Prof.Dr., Bilecik Şeyh Edebali University, Bilecik/ Turkey \\ E-Mail: cemalettin.hatipoglu@bilecik.edu.tr \\ ORCID: $\underline{0000-0002-3129-9725}$
}

\begin{abstract}
Effective use of information and communication technology in all aspects of economic and social life causes in improvements not just in manufacturing processes but also in other fields of life such as education, commerce, and social ties. As the societal system evolved, it was named "modern society," "technology society," and eventually "information society" in order to maintain quality of living, stability, and tolerance to this rapid transition. The information society can be described as a society that carries out all activities related to the transmission, storage, and dissemination of information by investing in computer-communication technology. With this definition, it is now necessary to explore the effect of knowledge on culture and social life in greater depth, as well as the countries' adaptation to this society. In Turkey, there are a few of dissertations on this subject. Our aim is to examine master and doctoral dissertations on the information society to determine which aspects of social existence are the most strongly linked. We searched dissertations that were published in the YOK (Yüksek Öğretim Kurumu) platform between 2010 and 2020. Tables will be used to provide the abstract details along with the social areas to which they are linked. In comparison, tables summarized and interpreted the years and departments the studies were studied more intensively in.
\end{abstract}

Keywords: Information and Communication Technologies, Industrial Society, Information Society. 


\section{Türkiye'de Bilgi Toplumana Bakış Açısı: Literatür Çalışması}

\section{Öz}

Bilgi ve iletişim teknolojilerinin ekonomik ve sosyal yaşamın her alanında etkin olarak kullanımı sadece iş süreçleri anlamında değil aynı zamanda eğitim, ticaret, sosyal ilişkiler gibi yaşamın her alanında değişimlere yol açmaktadır. Yaşam kalitesi, sürekliliği ve bu hızl değişime adaptasyonun să̆lanabilmesi için toplumsal yapının da değiştiği zaman içerisinde sanayi toplumu, teknoloji toplumu gibi isimler alarak son olarak "bilgi toplumu" olarak isimlendirilmeye başlanmıştır. Bilgi toplumu bilgisayar-iletişim teknolojilerine yatırım yaparak bilginin işlenmesi, toplanması, dă̆ıtımı ile ilgili tüm faaliyetleri gerçekleştiren toplum olarak ifade edilebilir. Bu tanımla birlikte bilginin toplum ve sosyal yaşam üzerinde ki etkisini detaylı bir şekilde araştırmak ve ülkelerin bu topluma adaptasyonunu araştırmak önemli hale gelmiştir. Bu konu da Türkiye de yapılmış olan birçok tez mevcuttur. Bizim amacımız bilgi toplumu üzerinde yapılmış olan yüksek lisans ve doktora tezlerini araştırmak ve sosyal yaşamın en çok hangi alanlarında ilişkisi olduğunu ortaya koymaktır. Bunun için 2010-2020 yılları arasında YÖK (Yüksek Öğretim Kurumu) sisteminde yayınlanmış tezleri araştırdık. Çalışmalara ait özet bilgiler, hangi sosyal alan ile ilişkisi olduğu tablolar halinde de özetlenerek sunulmuştur. Ayrıca çalışmaların hangi yıllarda ve hangi anabilim dallarında daha yoğun olarak çalışıldığı da tablolar halinde özetlenerek yorumlanmıştır.

Anahtar Kelimeler: Bilgi ve Iletişim Teknolojileri, Sanaayi Toplumu, Bilgi Toplumu. 


\section{Introduction}

As a result of advancements in information and networking technology, the transition to the digital world began with the information revolution. The usage of information as an input in development processes has had an effect on the global, political, social, and cultural world since the middle of the twentieth century. These results have shown themselves in the context of increased manufacturing productivity, the emergence of the service industry, a growth in qualified workforce, and a change in working styles, which we can see most clearly in economic life and job life. Information culture theorists have proposed important research on the course of these changes. Knowledge or information is the most valuable asset of the modern culture according to theorists (Toktaş, 2020). The history of economic revolutions and the advancement of technology demonstrate that information should be valued and regarded as the most valuable source of progress. Today, information-driven shifts and transitions have created a modern societal system under which knowledge is the primary turn in all aspects of existence. Most authorities refer to this new society as the "Information Society" or "Digital Age."

The information culture is distinct from most cultures, and a new social system develops as a result. Whether it is recognized as a process in which information is the important resource in any area from economy to other social systems, social existence governed by knowledge becomes one of the indispensable necessities of life.

In terms of social, economic, cultural, and political transition, significant and fundamental developments are occurring today. The key cause of these changes is the emergence of new information systems and the growing development of information. The origin of knowledge accumulation began with the human mind's questioning and analysis of all that exists in existence, and progressed with the creation of information that could be used. The continuous change of the social system has been brought on by the growth in information. The growth of informationbased industries has driven the development of an information-based culture. There has been a substantial growth in the amount of people, companies, and states that choose to adopt emerging technology, in addition to technical resources. Furthermore, advances in economic technologies 
have resulted in a rise in economic scale, and these changes in terms of both supply and transaction have opened the way for greater diversity. Globalization, competitiveness, and foreign competition have played a key role in states' political, financial, and social development, and have been a primary requirement for state comparison. All of these advances have influenced and ensured the growth of the knowledge society that remains today.

In this study, taking into account the dynamic and rapidly developing structure of the Information Society concept in Turkey, the master and doctoral dissertations completed in this field were analyzed. It is thought that that it is critical to discuss the topics studied in this area, to compare the history and present, and national policy objectives. So, our research covers master and doctoral dissertations completed between 2010 and 2020 (Bazı paragraflarda 2021 bazılarında 2020 yazılmıştır. Kullanılan kaynaklar göz önünde bulundurularak 2010-2020 olarak düzenlenmiştir). However, research on communication, information, social networking, and technological usage, as well as studies of the literature undertaken prior to 2010, are withdrawn from the reach. Both studies will be listed and chronologically described.

It is thought that the results of the research will contribute to the shaping of the studies and theses related to the concept of information society and to be associated with the existing policies.

The definition of the information society must be established before beginning the literature review. In the second chapter, studies reported in Turkey will be given in the order. In this section, they will be illustrated by graphics. At last, they would be discussed in the view of strengths, weaknesses, opportunities and threats.

\section{Definition of Information Society}

The information society is described as a social system that can generate all types of information, formed by information networks, provide and distribute the information, and can be applied to almost every industry and through which, that that is accessed (Kesici, 1993, p.62).

Although information society is defined as "a society that invests in computer-communication systems and departs from the industrial society 
in several ways" (İnan, 2003, p.397), another definition is "a society in which all operations relating to processing, storage, and distribution of information" ( Dura and Atik ,2002, p.272).

In the information society, the human factor and the accuracy of the information are critical. Information sticks out as one source emphasizing. Individuals in the information society are shown to have a much more responsive stance, tools for information and management are provided, and the knowledge economy is used as a field (Alakuş, 1991, p.11).

Even before identifying the information society and deciding the features of this model of society, a contrast to the industrial society is often made. The following are the basic characteristics of the knowledge society, each of which has various geographic characteristics (Arklan and Taşdemir, 2008, p.72):

- Following the agricultural and economic revolutions, which had significant effects and resulted in reforms, the information revolution's effects are still being found globally.

- In the information society, information is the most essential and valuable resource.

- Radical transition, rapid growth, and rapid information increase are the most significant characteristics of social life in the information society.

- The knowledge society has given rise to new job opportunities such as information processing, storage, and marketing.

- Intelligence professionals are being highly influential.

- Selectivity of information is expected to arise as a consequence of the accelerated growth of knowledge.

- Technology developments and advancements increase people's curiosity in where they reside.

- Information may play a significant role in the development of politics in the information society.

- The desire for constructive learning will persist throughout one's existence and will become more consistent.

- The most critical aim would be to gain experience and learn in the educational phase.

- Pointlessness in personal, social, and business life will disappear, and in areas where it remains, it will appear unappealing. 
- For working people, learning and incorporating new skills, creating and implementing new ideas will become more relevant, and diplomas will become less important.

- The human aspect can play a far larger role in these activities than it does now.

- Communication capabilities, cutting-edge computers, and technical advancements would pave the way for innovative systems to emerge, and knowledge will quickly expand.

The above are the fundamental variables of the information society. Information Technology (IT) is the technology that allows processes like information processing, capturing, storing, viewing, and distributing data to be performed accurately and efficiently (Bensghir, 1996, p.39).

Technology and Social Change: Technological advancements are inextricably linked to societal changes. The mechanism of technological advancement takes place within a societal system, and the cultures that use these inventions are the ones that carry it out. The social groups of society have made a significant contribution to the progress of inventions, and the impact of technical advancements on the social system can be observed. Technological advancements cannot be seen in distinction from time and space in this regard (Kara, 2017, p.124).

Computer-Based Information Systems: An information system is a framework that provides data for decision-making, process management, problem-solving, and the development of innovative services. These processes are carried out using input, output, and transaction steps. Internal or external data may be collected using the input. The product is the transfer of stored information for use, and the method is the stage of turning data into information. Information systems may also aid in the resolution of managerial or personnel matters, the identification of issues with a dynamic framework, and the development of innovative goods (Tahirov, 2009, p.123)

Communication Technology: Advances and rapid improvements in communication technologies allow different elements to communicate and use information. Industries that stay up with corporate life's advances in 
knowledge and communication-related systems have seen substantial increase in efficiency, which has a direct impact on global competitiveness. Changes in the economic environment with global consequences have become possible as a consequence of the impact of environmental innovations. However, the new reforms will only be successfully implemented in nations with a mature economic system. During the development process, several systemic issues arose in the economic systems. Problems that vary from state to state have arisen in the globalization phase as a result of variations in growth levels (Balkanll, 2002, p.24).

The Internet and the Knowledge System: The Internet is a global network that has developed in response to growing demands for producing, preserving, exchanging, and having access to information. The internet, which significantly enables quick access to any knowledge needed in everyday life or in particular, has resulted in a significant shift in social structure. The internet, which has a significant impact on local, national, and global economies, has also resulted in systemic improvements. One of the emerging technologies, the internet, has taken a significant role in this regard. Individuals and communities in developing countries may use the internet to keep up with trends in developed countries. In this regard, the internet has now been an essential component of knowledge structures (Ylmaz and Horzum, 2005, p.111).

Information Society and Globalization: Globalization, economic, cultural, and political integration, the use of opinions and ideas, technologies at the level of 15 states, the creation of sudden interactions outside the borders of the nation and state, the strengthening of competition, the liberalization of circulation, the growth of the market, and its spread around the world are all examples of today's globalization, economic, cultural, and political integration.

Knowledge Economy: Economic innovations are the primary drivers of societal change in the knowledge economy. In agricultural communities, for example, conducting economic activities by agriculture is effective. Because of the growth of industrial and industrial technology in the current economic operation of the time, the term "developed society" is used once 
more. Data and information technology are the basic development factors in the economic world, thus the word "information culture" is often used. Information technology is described as "the development and invention (innovation) skill in the field of advanced technology for the realization of industry and services" (Berberolu, 2010, p.144).

Technology has induced the advancement of information, and software has caused the spread of information. Societies that possess and control intelligence have become the birthplace of technology, dominating societies that are unable to implement digital technologies. Technology has been a form of influence that reproduces itself after economic and political wars have devolved into technology wars.

In this section, we tried to define the general characteristics of the information society, the basic variables that lead to the formation of the information society, together with the definition of information society. In the next section, literature studies of master's and doctoral theses published in Turkey between 2010 and 2020 will be included in the perspective of this definition, characteristics and variables.

\section{Literature Review}

Our research was to view the master or philosophies doctor thesis about information society in Turkey. The study technique was selected as the literature review of thesis published between 2010 and 2020. The literature study is given below in chronological order

Metin (2010), examined the impact of European Union Framework Programs on Turkish members on the basis of the Sixth Framework Program's Information Society Technologies aim. Its research process was based on a two- phase methodology. As the first phase, the DELPHI approach was applied to the decision makers of related stakeholders, their preferences were pointed out about the outcomes to which the Turkish partners could achieve; secondly, the impact levels and participants' responses were analyzed using a questionnaire. The participants had substantially high effects on scientific and technological influences, as well as establishing partnerships and increasing their understanding of the field, according to the survey's findings. Economic impacts, on the other hand, have been shown to be the lowest frequency of all the influence variables. 
Berberler (2010) investigated the contributions of the Ministry of National Education Information and Communication Technologies (MEBBS) to institutional functioning, as well as to make criticisms and recommendations based on the views of school administrators and teachers. For the study, a systematic assessment of the structural dynamics of the Ministry of National Education's position in education and the overall educational system, which is the director of policies, was investigated, and finally, the practical and functional roles of the ministry's research department were defined. The study found that information management applications like MEBBİS eliminate the time-consuming and paper-based processes that are a major issue in government. As a result, the Ministry of National Education eliminates inefficiency and ineffectiveness in the central and regional organizations' operational working. As a result, those infrastructures, requests, and criticisms by users should be investigated further, and any implementation problems, weaknesses, or errors that might exist should be addressed, and the system should achieve the highest degree of application.

In another similar study, educators and teachers were surveyed regarding the capacities and characteristics of the potential schools, as well as what is accomplished now and can be done to ensure today's schools are well-prepared for tomorrow's challenges. During the academic year 2008-2009, this descriptive situation determination study was conducted in 12 public and private elementary schools in Ankara. According to the finding of the survey, the increasing exchange of knowledge across the globe, advances in science and technology, evolving person expectations from schooling, internationalization, changing standards in society's culture, the need to reform educational systems, and the reasons that lead to change in traditional education understanding are all factors that lead to change in traditional education understanding. The current school system has been reported to be ineffective in addressing these reforms, with ineffective educational programs, administrator and teacher qualifications, physical facilities and technical resources, managers and teachers that are distant from technologies and advancements, and financial capital constraints. The existing school system must reform or transform because meeting the educational demands of the future (in order to cümle başinda kullanılmıştı. Cümlede ufak bir düzenleme yaparak yerine "because 
ving" kullanılmıştır). Reform will be realized in three ways: (1) making changes to the current curriculum and preparation programs, (2) strengthening the current qualification policies, and (3) including equal opportunities for both teachers and students (Savaş, 2010).

Cihangir (2010) studied the contributions of these libraries to academic life by investigating the major university libraries in European Union member countries. In this context, University libraries in Turkey were examined and compared with some university libraries in the EU. The description method, observation, and interview strategies were used to achieve the goal of the study (in order to yerine "to" kullanıldı ve cümle yeniden düzenlendi). According to the results of the study, university education policies can be redefined in a way that invests in information while still adhering to the concept of international cooperation. Universities should encourage academic research, and policy on researcher development should be updated. They should provide the necessary conditions for university libraries to conform to standards, collaborate, and follow technologies.

In other research, the facilities offered by faculty libraries of academic library forms Erciyes University Faculty of Economics and Administrative Sciences Library was compared with Colombia University Business and Economics Library. At the conclusion of this study, the Colombia University Business has been found to be more advanced in terms of service variety and quality than its library (Elverdi, 2011).

Ayaz (2012) purposed to explain the concept of information society. The relationship between the use of technology and the concept of information society was emphasized. It has been stated that utilizing technological products and living in an information environment are two separate concepts. Moreover, it has been evaluated that advanced technology products are also harmful to the country's economy due to their high cost.

Salur (2012) aimed to look into the connection between information economy criteria and economic development. The economic impact of the information economy was explained by providing comprehensive details on the growth, components, and general characteristics of the information economy. Two models were set established for the each of the two country groups categorized according to their geographical position and income 
level. The aim of them was to analyze the connection between the parameters of the information economy and economic development. They were based on Basic Scorecard model, the position of information economy index scorecard model and custom scorecard model. Results demonstrated that while the parameters of information society had a positive impact on per capita gross domestic product (GDP), they had no effect on per capita GDP in the second country group.

Koşaroğlu (2012) analyzed the impact of technology and information technology systems on the economy in terms of microeconomic and macroeconomic by describing the information society. It has been studied that the information being critical in the new-era social system was incorporate into the production function as a production element and its consequences on market competitiveness was clarified. The information generation capacity of countries was assessed in terms of research-development (R\&D) investments, technical staff employed in $R \& D$, patent approvals, research publishing surveys, and advanced technology exports. These criteria have been widely regarded as indices of information societies. As a result of the analysis, it was discovered that in countries with the ability to generate information, using the capacity of development has a growing impact on growth and economic development. In this sense, when assessing our country's ability to become an information society, the increased usage of information and communication technology, as well as R\&D investments, demonstrate that our country has gone forward in the right direction.

Uğraş (2012) investigated the habit of digital media usage in Turkey in the context of information society. Two questions were asked to young people aged 13-17 because young people are digital native. These questions were; what are the latest media behaviors of digital natives in Turkey? How did they identify the "information" concept? In this study, the significance of modern user's relationships with technology became clear when taken into account that members of the information society who engage in extensive usage of new media have had a more thorough understanding of the phenomenon of information. Also, this study recommended that technology producers carry out research and development studies in the direction of supporting information production and produce technology in this direction. Thus, they will also contribute to the 
young people gaining a place in environments that will make them more productive.

In other study, the development of the novel digital media definition was intellectualized in line with the paradigms of the newly established social system in the analysis by narrating the formation of social classifications and the transition from the agricultural society to the information society. The impact of convergence on media and news output were attempted to be measured with a survey conducted by news agency workers by referring to convergence within this current framework. While there was a definite trend in this direction among news agency staff, the existing arrangement was maintained and no improvements occurred as a consequence of the study. In this viewpoint, it is apparent that shifts in the business and customer structure, which are convergent, would be unavoidable. (Abanoz,2013).

Demir (2013) examined the social role of distance education, which will play a role in shaping the Information Society targeted by developing countries, and the social role of the Network-Based Distance Education Model, which is considered its most influential implementation. Implementations in European Union (EU) and Turkey and social outcomes of them were inquired in accordance with new education and training concept in information society, international projects and policies and their connection to advancing internet technologies

Görgülü (2013) aimed to assess the degree of technical leadership competencies of school administrators during the information society transformation. As a result of the study, it was discovered that the majority of school managers were skilled by getting training word processing, spreadsheets, presentations, the internet, e-mail, and instructional technology applications of school administration. Also, they did not use them because they receive training in the areas of databases, web page planning systems, animation programs, illustration programs, and the electronic board

Özutku (2014) addressed the concept of digital inequalities which emerged with the development of the information society. He determined the factors that contribute to digital inequalities and examined the mechanism established by international organizations to resolve physical and psychological inequality. 
The main purpose of K1lıç (2014) study is to measure how intensively a country uses information technologies, the contribution of information technologies to the formation of an information society, and to comparatively determine how efficiently countries realize this transformation. In comparison of Turkey to Finland, Ireland and France, the efficiency benefit of Turkey categorized least developed countries was higher than the benefit of Finland and poorer than the benefit of Ireland. Turkey had lower performance value than Ireland, Finland and France according to both input value and the Global Innovation Index- the Globalization Index being output value.

Koçak (2015) studied that the changes occurring in the understanding of human resources management in the transition process from the industrial society to the information society have been examined and its reflection on Public Administration has been emphasized. Result indicated that it was possible for public institutions to provide the services expected from them in the most effective and efficient way by switching from the classical personnel management understanding to the human resources management approach.

In other study, the aim was to explain the characteristics of the social structure changing from industrial society to information society and most importantly, what sociological changes the Turkish society has been subjected to due to this change. Also, it revealed the social, technology and training activities in the transition process of the information society in Turkey and her current situation. The ranking against other countries was analyzed with international statistics and the problems faced by the country and the precautions to be taken were evaluated. In this study, the concept of the information society was approached with a different perspective, and the exchange on the social structure of Turkey's information and communication technology has to be put forward. (İşbilen,2016).

Turhan (2016) attempted to describe the information society's traits, the current demographic dynamic and social framework known as dynamic and digital natives, and digital immigrants. At the conclusion of the report, a new plan for Turkey's information society was also discussed, focusing on the steps that could be taken directly prior to being Turkey's information society. 
Armağan (2018) studied the smart city phenomenon in the way of becoming an information society to find out what extent it is effective in spreading innovations and increasing participation. In this study, a quantitative research was conducted in Ankara. The result indicated that the factors that constitute the components of attitude towards smart cities has developed a positive attitude towards technological innovations, the studies of the Ankara Metropolitan Municipality, smart city functions and the understanding of participation. Therefore, the deployment of technological innovations has been found to support smart city formation and encourage participation. After all, such developments that support participation have been among the best practices presented in the way of becoming an information society. It has been concluded that it is possible to say that as smart city formations increase, the effect of this situation on participation will be positive.

Ezer (2018) argues that the most important feature of countries with information society is that they produce their own technologies and use these technologies in every field. He or she investigated the utilization rate for the personal use of information and communication technologies in Turkey in order to substantiate this claim.

Üçüncüoğlu (2018) defined e-sports being a new activity of today's information society, and tried to explain how it has become a part of modern sports. Within the scope of the study, the historical development of digital games and e-sports was examined and its interaction with modern sports was mentioned.

The thesis aims of Güner (2018) was to examine the contribution of the third wave development paradigm called the information society to the European Union's higher education policies in. The scope of it covered the innovation process in Denmark. It was concluded that the European Union higher education policies contributed positively to the innovation activities of the member countries. However, it has been found that these contributions vary in each member country according to their own research and innovation infrastructure and potential.

Gökmen (2019) analyzed individuals' shopping behaviors in the information society. As a consequence, he clarified that as the use of technology increases, individuals' habits change and they switched to e-commerce. 
Altıntaş (2019) aimed to obtain the views of school administrators about the document management system (DYS), which has become a necessity in the information society, and to examine their computer use skills and attitudes towards computers.

Lan (2019) investigated the interaction between digital marketing campaigns and word of mouth marketing in the information society period. The campaign's impact on Turkey and Vietnam was evaluated. The CocaCola Company's digital marketing strategies were examined and results emphasized that brand and brand recognition had influence in contact of Coca-Cola with the customer (Lan,2019).

The research aim of Eş (2019) was to evaluate the relationship between human resources management practices and innovation in the information society process. It was executed on blue-collar employees working in an electrical and electronics. According to frequency analysis, employees stated that the practices of the human resources management had positive and high effect on the innovation performance of the enterprise. In addition, it had been observed that there was a positive relationship between training and development, wage management practices from human resources practices, and innovation performance. As a result, it can be said that businesses can create processes that can benefit more from the potential of human resources, especially through training and development activities as increasing their innovative products and processes.

Karbuz (2019) studied the characteristics of the information society, how administratorship and in-service training are influenced from it, and what kind of policies should be followed on in-service training for managers in the information society. This thesis was conducted to find out how managers in Kocaeli Public Education Organizations decided the inservice training strategies.

Bakan (2019) assessed Turkey's action plan towards becoming an information society by defining information society. In addition, He introduced the departments required to be graduated and the course programs in order to become an information professional.

Bozaslan (2019) discussed Turkey's educational issues that threaten the nation's shift to the Information Society. He proposed a response model 
consisting of guidelines, instructional practices, and procedures to be utilized in education, a teacher-student model, and educating teachers that would shape the information society.

The thesis aim of Kirtay (2020) was to explore how we can profit from technological elements to obtain knowledge in the quickest and most precise manner possible in the way of becoming an information society, and to demonstrate the value of our youth using technology correctly and effectively. According to the results, it was understood that there was a negative relationship between technology addiction and reading habits. When analyzed by gender, it was found that female students had more reading habits than male students, but there was no significant difference between male and female students in terms of technology use. In addition, it was found in the study that female students use the internet more for educational purposes than male students, while male students spend more time on online games than female students.

Ölmez (2020) attempted to identify the concept of intellectual capital in the information society. The aim of this analysis was to determine the relationship between the success of technology-based businesses and the management of intellectual capital. It has been shown that when technology companies develop their intellectual capital assets, they achieve digital transformation, enhance their productivity and their market efficiency.

Toktas (2020) examined the development of the information society in a theoretical framework and its interaction with flexible working. Explanations about the information society and flexible working were made and the qualities of new current forms of flexible working are analyzed in the axis of the Fourth Industrial Revolution discussions. It was determined that in this work style, where employees are mostly freelancers, jobs are usually short and temporary. Also, Toktas concluded that new flexible working styles are becoming more widespread and more risky and uncertain in this period and it will bring new problems with it.

Teke (2020) sought the answers of the questions of how professional studies were affected by the transformations experienced in the information society, to what extent they meet the need for lifelong learning and to what extent the activities applied in these studies coincide with the principles of adult education Professional studies were frequently revised, 
but not sufficient. Teachers' expectations also increase for adapting to students raised in the information society and to understand generations (in order to yerine for ving kullanıld1). For this reason, it is thought that methods, subjects and contents should be updated in in-service trainings in the 21 st century. The emphasis should be placed on application-oriented skill development rather than subject transfer, because it seems that technology literacy and information literacy are essential needs for teachers today.

Nas (2020) evaluated the effects of transition to the information society and surveillance society. As a result, surveillance technologies and information were quite inconvenient for the individual to become data, uniformed individuals and change the perception of privacy. All posts in private areas were brought to the public domain with a single click. This was both a violation of privacy and a violation of ethical rules. All surveillance activities carried out without the consent of the individual or without the consent of the individual should be considered a violation of the code of ethics.

The master's and doctoral theses distribution graphs from the studies we looked at are seen in table 1, with the years indicated. 28 master and 5 doctoral dissertations on information society were written in Turkey between 2010 and 2020. Table 1 indicated that 2019 was the most studied year of 33 studies for dissertations. There were a total of seven articles, with six of them falling under the master's thesis category and one falling under the doctoral thesis category. 2020 is following 2019. In all, there are five reports. Four of the theses are master's theses, and one is a doctoral dissertation.

It has also been observed that information society mostly took part in master thesis studies between 2010 and 2015. The first study in the field of doctorate was in 2012. Later, in 2016, study in the field of doctorate again was found. This has created the impression that the subject of "information society" has matured over time and has been included in the scope of research topics. 2019 is observed as the year in which the most study was done. 7 of the 6 studies are master's and 1 doctoral dissertation. This is followed by the year 2020 and 5 thesis studies, 4 of which are master's and 1 doctorate, have been found. 
Table 1. Doctoral and Master's Thesis Distribution by Years

\begin{tabular}{llllllllllll}
\hline & $\mathbf{2 0 1 0}$ & $\mathbf{2 0 1 1}$ & $\mathbf{2 0 1 2}$ & $\mathbf{2 0 1 3}$ & $\mathbf{2 0 1 4}$ & $\mathbf{2 0 1 5}$ & $\mathbf{2 0 1 6}$ & $\mathbf{2 0 1 7}$ & $\mathbf{2 0 1 8}$ & $\mathbf{2 0 1 9}$ & $\mathbf{2 0 2 0}$ \\
\hline Master & 4 & 1 & 3 & 3 & 2 & 1 & 1 & - & 2 & 6 & 4 \\
\hline Ph.D. & - & - & 1 & - & - & - & 1 & - & 2 & 1 & 1 \\
\hline
\end{tabular}

Table 2. Institute-by-Institute Scatter Table

\begin{tabular}{llllllll}
\hline Institutes & $\begin{array}{l}\text { School Of } \\
\text { Graduate } \\
\text { Studies }\end{array}$ & $\begin{array}{l}\text { Institute } \\
\text { of Busi- } \\
\text { ness }\end{array}$ & $\begin{array}{l}\text { The Institute } \\
\text { of } \\
\text { Studies }\end{array}$ & $\begin{array}{l}\text { Social } \\
\text { Turkish } \\
\text { tute }\end{array}$ & $\begin{array}{l}\text { Sci- } \\
\text { Insti- }\end{array}$ & $\begin{array}{l}\text { Institute of } \\
\text { Education } \\
\text { Sciences }\end{array}$ & $\begin{array}{l}\text { Institute } \\
\text { of } \\
\text { ence }\end{array}$ \\
\hline Numbers
\end{tabular}

Table 2 presents summarized information to determine in which institutes the studies we have examined are published. When we examined this table, it was observed that the theses were mostly published in the social sciences institute. There are business departments in the category of institute of social sciences. Science and educational sciences institutes followed. In this case, we can comment that "information society" studies are mostly in the field of social sciences.

Studies published in the literature were categorized into three groups based on the topic of research. Education, industry-business, and sociology are the three groups. Library programs, elementary and higher school education research were also used in the education category. Trade, human resources, economy, finance, and market processes in both the private and public sectors were also part of the sector-business segment. There were articles on the information society and the effect of technological use on society in the sociology category. The key purpose of this grouping is to see which types of studies reported as theses get the most attention. Table 3 shows the relationship between these groups and the number of information society studies published over time. When we look at it separately, we find that 12 studies focus on the interaction between information society, social life, and sociological transition, and they have the highest frequency importance. The other two groups were evenly divided. According to Table 1, the year in which the most testing was accomplished was 2019. When we look at which group has the most research, we see that all groups are evenly divided, with four out of seven studies looking at "the influence of the information society on education," and three looking at the effects on the business field. The year 2020 comes after the year 2019. There are a total of five reports. The impact of the 
knowledge society on education, industry-business, and sociology are among the 2020 study topics. Although sociology and sector-business studies are almost evenly spread each year, it has been established that the majority of studies in the field of education have been conducted in recent years, especially in 2019.

Table 3. Categorical Analysis Based on Years

\begin{tabular}{|c|c|c|c|c|c|c|c|c|c|c|c|}
\hline & 2010 & 2011 & 2012 & 2013 & 2014 & 2015 & 2016 & 2017 & 2018 & 2019 & 2020 \\
\hline $\begin{array}{l}\text { Educa- } \\
\text { tion }\end{array}$ & 2 & 1 & 2 & 2 & - & - & 1 & - & - & 4 & 1 \\
\hline $\begin{array}{l}\text { Sector } \\
\text { Work }\end{array}$ & 2 & - & - & - & - & 1 & - & - & - & 3 & 2 \\
\hline $\begin{array}{l}\text { Sociol- } \\
\text { ogy }\end{array}$ & - & - & 2 & 1 & 2 & - & 1 & - & 4 & - & 2 \\
\hline
\end{tabular}

\section{Conclusion}

We may assume that the primary goal of transforming countries into information societies around the world is to improve their competitiveness and social security while growing their share of the global capital share. Successful usage of information and communication technology in all aspects of economic, education and social existence becomes critical in order to achieve this goal. This is also supported by the thesis results we studied into.

In Turkey, the information society has been on the agenda since the second half of the 1990s, when machines were widespread. Through the increasing usage of machines and the internet that followed, the idea that "the industrial era is finished" and that "we can access any knowledge because we are linked to the internet" has taken hold. Still now, some of us might believe this to be so. Apart from that, there are two major issues. The first issue is that simply placing a machine on a table would not constitute an information society or an information era. The most critical factor is to be able to use the machine accurately and safely. Individually, effective information must be obtained, as well as the ability to generate information and interactive technologies in a social setting. The "blog" is the second. The Internet gives users access to unsourced details rather than scientific expertise. The most critical issue, though, is to create and access scientific information 
The Prime Ministry's Under secretariat, the Turkish Intelligence Foundation, the Turkish Informatics Association, the Turkish Informatics Foundation, and the Turkish Information Technology Services met in Ankara between the 10th and 12th of May 2002 to discuss how to transform our country into an information society and what strategies are required for a structure that both uses and produces information. The Association founded the "Informatics Council of Turkey." Working groups on the advancement of Turkey's informatics market, connectivity technology, eeconomy, e-government, regulation, education, and R\&D have been established as part of the council's studies (Türkiye Bilişim Şurası, 2002a, p.2). Both of these preparations and workshops demonstrate that our country's work on this subject is inconsistent. Despite political peace, the question of transitioning to a knowledge society is not provided sufficient attention, and ongoing studies are not conducted. Any time should discuss the developments and transitions brought on by knowledge and communication technology in human relations, as well as the society's direction. Begin by typing or pasting something into this box, then touch the enter key.

Independent studies were collected under a common project and attempted to be accelerated with the "e-Transformation Turkey Project," which began in Turkey in 2003. The aim of this project is to ensure that the transition of the whole world into a knowledge society is carried out in a coordinated manner between individuals, businesses, and the general public. The e-Transformation Turkey Executive Board planned and approved "Turkey's Information Society Improvement Policy." Turkey's vision of being an information society has been described in this transformation policy document as a country that has become a focal point in the production of science and technology, uses information and technology as an effective tool, produces more value through information-based decision-making processes, is successful in global competition, and has a high level of production (2016, E-Devlet Kapisi) Looking at this concept, it's obvious that the primary focus is on the producer. Turkey must first turn its youth demographic into "active citizens" to realize this vision (in order to yerine "to" kullanıld1). The initiation of this phase goes into schooling.

TÜBTAK has described Turkey's vision for 2023, the 100th anniversary of our Republic, as "Turkey Leading in the Information Age Industries." 
In order for Turkey to accomplish this aim, colleges and science centers, which are knowledge era manufacturers, must be given the attention they deserve.

The key criterion for a country to be a knowledge society is for its citizens to have attained "information society" awareness. It is more difficult to develop as a nation if the citizens residing in your land are unaware of the value of knowledge, no matter how hard you operate as a state. This knowledge is created by a well-functioning and healthy educational system.

One of the most important phenomena that the information society has changed with its arrival is the phenomenon of education. Education is gaining more importance than ever before, and it is becoming a much debated issue in the society. The role of knowledge in the knowledge society has gained more importance than in the industrial society. Periodic education in the industrial society has been replaced by individualized lifelong learning. The human profile to be raised in the information society has changed. In the information society, people who can use information more effectively and benefit from information are needed. For this, people need to be educated in this direction. This is the task of the educational process. In this society where technology is one step ahead, an efficient education should be provided in order to give the necessary importance to the individual.

The most important difference between countries that meet the requirements for being classified as an information society and other countries is the emphasis they place on the knowledge economy. The information ecosystem is a critical phase in a country's growth, affecting everything from culture to everyday life, education to health. Many multinational organizations compare growth and prosperity across different countries' economic levels.

Universities share a great responsibility in our country's transition to a knowledge age. Universities can incorporate knowledge and networking technology into their undergraduate programs as soon as possible, and make the idea of the information society a part of society's everyday lives. Since incidents and phenomena are commonly treated inside conventional patterns in our world, innovation is not possible. This condition is a significant impediment to the development of a knowledge society. As 
a result, an aggressive competitiveness policy, as well as suitable educational and cultural policies, must be implemented since maturing the dynamic and efficient business environment.

The rate of schools connecting to the internet is about 99 percent in communities that have undergone the transition phase into an information society. As educational institutions in a nation are linked to the internet, the volume of material in circulation increases, making it possible for all who pursue knowledge and training in those educational institutions to access information from all over the world. As a result, one of the major obstacles to Turkey's transformation to an information culture is that the application of information and networking technology has not extended to the general population.

For the information society, knowing and also utilizing previous experience in the future is a must. However, the term "information society" refers to a society with a large number of academics who, in addition to collecting information, may create and use new ones based on it. For instance, if we can store all of the world's knowledge in Turkey using an information distribution network, Turkey might theoretically become a "information society."

Turkey will only win this difficult race if it has a thriving informatics sector that produces its own jobs. Both the government and the business sector share significant roles in achieving this aim. The information age is a societal problem. It's difficult to address this problem using just economic reasoning. However, it is important to examine the outcomes of the structural changes that the world is undergoing. We are also members of the information society and live in the technology age.

\section{References}

Abanoz, E.(2013). Bilgi toplumunda yöndeşmenin haber üretimi süreci üzerindeki etkisi: Haber ajansı çalı̧̧anları üzerine bir araştırma. Yayımlanmamış Yüksek Lisans Tezi. Marmara Üniversitesi, Sosyal Bilimler Enstitüsü, İstanbul.

Alakuş, M. (1991). Bilgi Toplumu. Ankara: TC Kültür Bakanlığı Yayınları.

Altıntaş, İ. (2019). Bilgi toplumunda bir e-devlet uygulaması olarak DYS hakkında okul yöneticilerinin görüşleri. Yayımlanmamış Yüksek Lisans Tezi. Çanakkale Onsekiz Mart Üniversitesi, Eğitim Bilimleri Enstitüsü, Çanakkale. 
Arklan, Ü. and E. Taşdemir (2008). Bilgi toplumu ve iletişim: Bilginin yayılması sürecinde kitle iletişim araçları ve internet. Selçuk Üniversitesi İletişim Fakültesi Akademik Dergisi,5(3), 67-80.

Armağan, M. V. (2018). Bilgi toplumunda akıll şehirler ve katilımo yurttaşlk. Yayımlanmamış Doktora Tezi. Gazi Üniversitesi, Sosyal Bilimler Enstitüsü, Ankara.

Ayaz, M. ( 2012). Hizla gelişmekte olan (BRIC) ülkelerde bilgi toplumu ve sosyal sermaye etkileşimi: Türkiye karşılaştırması. Yayımlanmamış Yüksek Lisans Tezi. Yalova Üniversitesi, Sosyal Bilimler Enstitüsü, Yalova.

Bakan, Ö. (2019). Bilgi toplumu stratejileri açısından Türkiye'de kamu sektöründe çalş̧an arşiv personelinin durum analizi: Tapu arşiv personeli örneği. Yayımlanmamış Yüksek Lisans Tezi. Marmara Üniversitesi, Türkiyat Araştırmaları Enstitüsü, İstanbul.

Balkanlı, A. O. (2002). Küresel Ekonominin Belirleyici Faktörleri Üzerine. Uludağ Üniversitesi İktisadi Ve İdari Bilimler Fakültesi Dergisi, 21(1), 13-26.

Berberler, R.(2010). Bilgi toplumuna geçiş sürecinde Türkiye: Bir kamu kurumunda bilgi teknolojileri kullanımma ilişkin bir araştırma. Yayımlanmamış Yüksek Lisans Tezi. Celal Bayar Üniversitesi, Sosyal Bilimler Enstitüsü, Manisa.

Berberoğlu, B. (2010). Bilgi toplumu ve bilgi ekonomisi oluşturma yolunda Türkiye ve Avrupa Birliği. Marmara Üniversitesi IÏBF Dergisi, 29, 111-131.

Bensghir Kaya, T. (1996). Bilgi teknolojileri ve örgütsel değişim. Ankara: TODAiE Yayınları.

Bozaslan, H.(2019). Eğitim açısından Türkiye'de bilgi toplumu yapısına geçişi engelleyen faktörler. Yayımlanmamış Doktora Tezi. İnönü Üniversitesi, Eğitim Bilimleri Enstitüsü, Malatya.

Cihangir, Y.(2010). Avrupa Birliği bilgi toplumu projeleri ve üniversite kütüphaneleri. Yayımlanmamış Yüksek Lisans Tezi. Marmara Üniversitesi, Türkiyat Araştırmaları Enstitüsü

Demir, C. (2013). Bilgi toplumuna geçiş sürecinde uzaktan eğitimin rolü. Yayımlanmamış Yüksek Lisans Tezi. Ege Üniversitesi, Fen Bilimleri Enstitüsü, İzmir.

Dura, C. and Atik, H. (2002). Bilgi toplumu, bilgi ekonomisi ve Türkiye. İstanbul: Literatür Yayınclik.

Elverdi, S.(2011). Bilgi toplumu sürecinde Erciyes Üniversitesi İ. İ. B. F. Kütüphanesi: Uluslararası bir karşılaştırma. Yayımlanmamış Yüksek Lisans Tezi. Erciyes Üniversitesi, Sosyal Bilimler Enstitüsü, Kayseri. 
Eş, A. (2019). Bilgi toplumu sürecinde insan kaynaklar yönetimi ve inovasyon. Yayımlanmamış Yüksek Lisans Tezi. Bolu Abant İzzet Baysal Üniversitesi, Sosyal Bilimler Enstitüsü, Bolu.

Ezer, M.(2018). Türkiye'de bilgi toplumunun gelişimi: Kişisel internet kullanım amaçları üzerine bir uygulama. Yayımlanmamış Yüksek Lisans Tezi. Çukurova Üniversitesi, Sosyal Bilimler Enstitüsü, Adana.

Gökmen, K. (2019). Bilgi toplumunda elektronik ticaret ve Türkiyeörneği. Yayımlanmamış Yüksek Lisans Tezi. İstanbul Üniversitesi, Sosyal Bilimler Enstitüsü, İstanbul.

Görgülü, D. (2013). Bilgi toplumuna geçiş sürecinde okul yöneticilerinin teknolojik liderlik yeterlilikleri açısından incelenmesi: Konya ili örneği. Yayımlanmamıs Yüksek Lisans Tezi. Atatürk Üniversitesi, Eğitim Bilimleri Enstitüsü, Erzurum.

Güner, O. (2018). Bilgi toplumunda Avrupa Birliği yükseköğretim politikalarnnn yenilik faaliyetleri üzerindeki etkinliği: Danimarka örneği. Yayımlanmamış Doktora Tezi. İstanbul Üniversitesi, Sosyal Bilimler Enstitüsü, İstanbul.

İşbilen, F. M.( 2016). Sanayi toplumundan bilgi toplumuna geçiş sürecinde insan kaynaklarn yönetiminde ortaya çkkan Bilgi toplumuna geçiş sürecinde Türkiye. Yayımlanmamış Yüksek Lisans Tezi. Kırıkkale Üniversitesi, Sosyal Bilimler Enstitüsü, Kurkkale.

Kara, S. (2017). Teknoloji ve toplumsal değişim ilişkisinin Sosyal İnşa Kuramı bağlaminda incelenmesi. Dört Öge, 6(12), 117-131.

Karbuz, N.(2019). Bilgi toplumu sürecinde kamu eğitim yöneticilerine yönelik hizmet içi eğitim politikalarnndaki değişim. Yayımlanmamış Yüksek Lisans Tezi. Sakarya Üniversitesi, Sosyal Bilimler Enstitüsü, , Sakarya.

Kesici, İ. (1993). Bilgi toplumunun özellikleri. Bilişim, Mayıs 1993, 62-67.

Kılıç, Ç. (2014). Çoklu bağlantı olgusunun bilgi toplumu oluşturmadaki rolü: Ülkeler arasında verimlilik esash bir karşılaştırma. Yayımlanmamış Yüksek Lisans Tezi. Bahçeşehir Üniversitesi, Fen Bilimleri Enstitüsü, İstanbul.

Kurtay, O.(2020). Gaziantep ili Şahinbey ilçesinde öğrenim gören ortaöğretim 9. sinff öğrencileri özelinde bilgi toplumu ve dijital kültür kavramı arasındaki ilişkinin incelenmesi. Yayımlanmamıs Doktora Tezi. İstanbul Üniversitesi, Sosyal Bilimler Enstitüsü, İstanbul.

Koçak, M.(2015). Sanayi toplumundan bilgi toplumuna geçiş sürecinde insan kaynaklarn yönetiminde ortaya çıan değişimler ve Türk kamu yönetiminde insan kaynakları yönetimi anlayışı. Yayımlanmamış Yüksek Lisans Tezi. Gazi Üniversitesi, Sosyal Bilimler Enstitüsü, Ankara. 
Koşaroğlu, Ş. M.(2012). Bilgi toplumu ve bilginin ekonomik dönüşümdeki rolü. Yayımlanmamış Yüksek Lisans Tezi. Cumhuriyet Üniversitesi, Sosyal Bilimler Enstitüsü, Sivas.

Lan, L.T.N. (2019). Bilgi toplumunda dijital pazarlama stratejileri ve ağızdan ağıza pazarlama ilişkisi üzerine bir uygulama. Yayımlanmamış Yüksek Lisans Tezi. Marmara Üniversitesi, Sosyal Bilimler Enstitüsü, İstanbul.

Metin, H.(2010). Assessing impacts of the European framework programme on Turkish participants: A case study on framework programme6 ist priority. Yayımlanmamış Yüksek Lisans Tezi. Orta Doğu Teknik Üniversitesi, Fen Bilimleri Enstitüsü

Nas, M.(2020). Bilgi toplumu ve gözetim teknolojileri. Yayımlanmamış Yüksek Lisans Tezi. Muş Alparslan Üniversitesi, Sosyal Bilimler Enstitüsü, Muş.

Ölmez, T.(2020). Yeni ekonomi ve bilgi toplumunda entelektüel sermayenin yeni kurallar ve bir uygulama. Yayımlanmamış Yüksek Lisans Tezi. Marmara Üniversitesi, Sosyal Bilimler Enstitüsü, İstanbul.

Özutku, F.(2014). Bilgi toplumunun oluşumunda dijital eşitliğin sağlanmasınm önemi. Yayımlanmamış Yüksek Lisans Tezi. Gazi Üniversitesi, Sosyal Bilimler Enstitüsü, Ankara.

Salur, S. (2012) . Bilgi toplumu parametreleri ve ekonomik büyüme arasindaki ilişki: Panel analiz. Yayımlanmamış Doktora Tezi. Adnan Menderes Üniversitesi, Sosyal Bilimler Enstitüsü, Aydın.

Savaş, Ç.(2010). Bilgi toplumunda geleceğin okullarna ilişkin yönetici ve öğretmen görüşleri. Yayımlanmamış Yüksek Lisans Tezi. Ankara Üniversitesi, Eğitim Bilimleri Enstitüsü, Ankara.

Tahirov, A. (2009). Bilgisayar Destekli Bilgi Sistemleri. Journal Of Qafqaz University, 27, 123-133.

Teke, D.(2020). Bilgi toplumunda yaşam boyu öğrenme ve yetişkin eğitimi: Öğretmenlerin mesleki çalışmalar üzerine bir araştırma. Yayımlanmamış Yüksek Lisans Tezi. Sakarya Üniversitesi, İsletme Enstitüsü, Sakarya.

Toktaş, D.(2020). Bilgi toplumu kuramlan bağlamında esnek çalışma. Yayımlanmamış Yüksek Lisans Tezi. İstanbul Üniversitesi, Sosyal Bilimler Enstitüsü, İstanbul.

Turhan, D. G. (2016). Bilgi toplumu kavramı çerçevesinde dijital yerliler ve dijital aktivizm. Yayımlanmamış Doktora Tezi. Süleyman Demirel Üniversitesi, Sosyal Bilimler Enstitüsü, Isparta.

Uğraş, T. (2012). Türkiye'deki dijital yerlilerin yeni medyayı kullanım alışkanlkklarını bilgi toplumu bağlaminda incelenmesi. Yayımlanmamış Yüksek Lisans Tezi. İstanbul Üniversitesi, Fen Bilimleri Enstitüsü, İstanbul. 
Üçüncüoğlu, M.(2018). Bilgi toplumunun sportifbir yansiması olarake-spor ve modern spor ile etkileşimi. Yayımlanmamış Yüksek Lisans Tezi. İstanbul Üniversitesi, Cerrahpaşa Lisansüstü Eğitim Enstitüsü, İstanbul.

Yılmaz, K. and B. Horzum (2005). Küreselleşme, Bilgi Teknolojileri ve Üniversite. İnönü Üniversitesi Eğitim Fakültesi Dergisi, 6(10), 103- 121.

https://wwww.tbd.org.tr/turkiye-bilisim-surasi-2002/ TÜRKIYY BILISSiM ŞURASI 2002 (01.05.2021)

\section{Citation Information}

Tunacan, T. and Hatipoğlu, C. (2021). Information society perspective in Turkey: Literature study. OPUS-International Journal of Society Research, 18(41), 3729-3754. DOI: 10.26466/opus.937283. 